Department of Animal Physiology,

Faculty of Animal Production, University of Geizra, Sudan.

\title{
CHEMICAL COMPOSITION, IN VITRO GAS PRODUCTION, METABOLIZABLE ENERGY AND ORGANIC MATTER DIGESTIBILITY OF LEAVES AND SEED FRACTIONS OF THE TREE BALANITE AEGYPTIACA \\ (With 2 Tables and One Figure)
}

By

\section{M.G. MORKAZ; SHAMSELDEIN H. AHMED and SHADIA A. OMER}

Department of Biomedical Science, College of Veterinary Medicine, Sudan University of Science and Technology, Sudan.

E.mail; shamshahmed@sustech.edu or shamshahmed@yahoo.com

(Received at 20/3/2011)

\section{SUMMARY}

Chemical composition, in vitro gas production, metabolizable energy and organic matter digestibility of the tree Balanites aegyptiaca leaves and seed fractions were determined. The objective was to asses the potential of fruit and leaves of Balanites aegyptiaca as ruminant feed. Gas production was measured for 3, 6, 12, 24, 48, and 72 hours, and gas production kinetics were estimated using the equation $\mathrm{y}=\mathrm{a}+\mathrm{b}\left(1-\exp ^{-\mathrm{ct}}\right)$. The results showed that, the crude protein $(\mathrm{CP})$, crude fiber $(\mathrm{CF})$, ether extract (EE) gas production, gas production kinetics, organic matter digestibility (OMD) and metabolizable energy (ME) were significantly different $(p<0.01)$ between leaves and seed fractions. Seed kernel cake showed the highest CP content, OMD and lowest CF content, whereas the flesh showed the highest EE, Nitrogen free extract (NFE), gas production at all the time of incubation, gas production from the soluble and insoluble fractions, potential gas production and ME content. It is concluded that, kernel seed cakes, and flesh (pulp) of B. agyptiaca are outstanding and they have high potential as ruminant feed, as carbohydrate and protein supplement to low quality tropical basal diets. In addition to chemical analysis, in vitro gas production technique found to be a reliable predict to the nutritive value. 
Key words: B.aegyptiaca seed cake, gas production, metabolizable energy

\section{INTRODUCTION}

The tree Balanites aegyptiaca, (Hegleig) is indigenous to of Africa south of the Sahara (Hall and Walker, 1991). The tree is also found in India, Iran and Pakistan (Amalraj and Shankarnarayan, 1986). In the Sudan it has wide natural range, occurring in all climates (Badi et al., 1989). In Africa Balanites aegyptiaca had been used as food and oil source (Von Maydell, 1986). The fleshy pulp of the fruit is eaten fresh or dried. It contains $64-72 \%$ carbohydrates, plus crude protein, (Abu Al-Futuh, 1983). Balanites seed kernel is considered as an extremely useful edible product. It contains good quality oil and high protein content (Abu Al- Futuh, 1983; Mohamed et al., 2002). The extracted oil used for many uses and the remaining cake is used as animal feed (El-Nour et al., 1985). The protein content of kernel ranged between 27\% -37\% (Abu Al-Futuh 1983; El Khideir et al., 1983; Mohamed et al., 2002; Elfeel, 2010).

Balanites aegyptiaca contributed up to $30 \%$ of the dry matter intake of goats in the dry season in Burkina faso (Hall and Walker, 1991). The kernel meal is used for fattening of sheep in the Sudan (Elkhideir et al., 1983), for fattening other animals in Senigal (Vogt, 1995) and as stock feed in Uganda. (Katende et al., 1995). The flesh (pulp) of B. aegyptiaca fruits contains, on average, $10.9 \%$ moisture, 2.7\%ash, $1.4 \%$ protein, (Guinand and Dechassa lemessa, 2002).

It is not always possible to evaluate the nutritional characteristics of the individual feed component in a complex feeding experiment. For these reasons there have been a number of attempts to develop rapid, simple reliable and cheap in vitro methods which can be used to screen large numbers of raw materials and predict their digestibility and metabolizable energy contents. Menke et al. (1979) developed the in vitro gas production technique to evaluate the nutritive values of feedstuffs. The in vitro gas production is a method that detects a small difference among feedstuffs and allows more frequent sampling than the in vitro digestibility technique (DePeter et al., 2003). The gas produced during fermentation can be used as an indirect measure of the dry matter degradability. The gas produced in $24 \mathrm{~h}$ from incubating $200 \mathrm{mg}$ feed dry matter can be used together with the concentration of crude protein and ash to estimate metabolizable energy and organic matter digestibility 
Menke et al. (1979). Gas production is associated with volatile fatty acid production following fermentation of the substrate so the more fermentation of a substrate the greater the gas production (Blummed and Ørskov 1993). The in vitro gas production technique has been found reliable to predict the nutritive value of feedstuffs (Maker et al., 1996). In vitro gas production method has been used to compare different species of sorghum grain and forage quality (Streeter et al., 1993; Opatpatanakit et al., 1994).

The objective was to assess the potential of fruit and leaves of Balanites aegyptiaca as ruminant feed.

\section{MATERIALS and METHODS}

\section{Collection of samples:-}

Fresh ripe fruits of Balanites aegyptiaca were collected from Kordofan State local market. The seed were cleaned and sun dried and stored in bags for further processes.

\section{Preparation of fruits and leaves:}

The coat (outer cover) and the flesh (mesocarp) of the fruits were removed manually; then the flesh was sun- dried. The leaves were collected manually from the trees. The kernel was produced by mechanical decortication of the ripened fruit seed. The kernel cake was obtained by mechanical extraction of the oil, from the decorticated seeds, as described by Chapagain and Wiesman, (2005).

\section{Chemical analysis:-}

Proximate analysis for chemical components (dry matter (DM), crude protein (C.P) crude fiber (C.F), ether extract (E.E) and ash) were determined by the methods described by the AOAC (1990).

\section{Gas production study:}

Rumen fluid was obtained from two fistulated steers fed alfalfa hay ad libitum and $1 \mathrm{~kg}$ of concentrate mixture. The samples of fruits and leaves were incubated in the rumen fluid in calibrated glass syringe following the procedures of Menke and Steingass (1988). 200 milligrams $(\mathrm{mg})$ dry weight sample was weighed in triplicate into calibrated glass syringes. The syringes were pre-warmed at $39^{\circ} \mathrm{C}$ before injecting $30 \mathrm{ml}$ rumen fluid-buffer mixture into each syringe followed by incubation in a water bath at $39^{\circ} \mathrm{C}$. The syringes were gently shaken for $30 \mathrm{~min}$ after the start of incubation and then after every hour for the 
first 10 hours of incubation. Gas production was recorded before incubation (0) and 3, 6, 9, 12, 24, 48 and $69 \mathrm{~h}$ after incubation. Total gas values were corrected for blank. Cumulative gas production data were fitted to the model of Ørskove and Mc Donald (1979) using the following equation.

$\mathrm{P}=\mathrm{a}+\mathrm{b}\left(1-\exp ^{-\mathrm{ct}}\right)$. Where:

$\mathrm{P}$ : represent gas volume $(\mathrm{ml})$ at time $\mathrm{t}$.

a: the gas produced from immediately soluble fraction $(\mathrm{ml})$.

b: the gas produced from insoluble fraction "but fermentable" (ml).

$(\mathrm{a}+\mathrm{b})$ : the potential gas production $(\mathrm{ml})$, and

c: the rate constant of gas production during incubation ( $\mathrm{ml} \mathrm{h}-1)$.

The OMD was calculated using equations of Menke et al. (1979) as follows:

OMD $(\%)=14.88+0.889 \mathrm{GP}+0.45 \mathrm{CP}+\mathrm{XA}$, Where

$\mathrm{GP}=24 \mathrm{~h}$ net gas production $(\mathrm{ml} / 200 \mathrm{mg}), \mathrm{CP}=$ Crude protein $(\%)$

$\mathrm{XA}=$ Ash content $(\%)$.

$\mathrm{ME}(\mathrm{MJ} / \mathrm{kg} \mathrm{DM})$ content was calculated using equations of Menke et al $(1979)$ as follows: $\mathrm{ME}(\mathrm{MJ} / \mathrm{kg} \mathrm{DM})=2.20+0.136 \mathrm{GP}+0.057 \mathrm{CP}+$ $0.0029 \mathrm{CP}^{2}$.

Where .GP is $24 \mathrm{~h}$.production $(\mathrm{ml} / 200 \mathrm{mg})$.

$\mathrm{CP}=$ Crude protein: $\mathrm{CF}=$ Crude fiber.

\section{Statistical analysis:}

Data were subjected to one way analysis of variance (ANOVA) to compare gas production kinetics, OMD and $\mathrm{ME}$ values using the General Linear Model (GLM) according of statistica, (Analytical software, 2000). Significant differences between individual means were separated by the least significant differences using LSD procedure of the statisticx (analytical software, 2000). Differences between means were considered significant at $\mathrm{P} \leq 0.05$. Standard errors of means were calculated from the residual mean square in the analysis of variance. 


\section{RESULTS and DISCUSSION}

Table 1: Chemical component \%of the leaves, coat (Hull), flesh (Pulp) and kernel seed cake of $B$. agyptiaca (means $\pm \mathrm{SD}$ )

\begin{tabular}{|c|c|c|c|c|c|c|}
\hline Part & DM\% & $\mathrm{EE} \%$ & $\mathrm{CP} \%$ & $\mathrm{CF} \%$ & Ash\% & NFE\% \\
\hline Leaves & $89.51 \pm \cdot .06^{\mathrm{c}}$ & $9.04 \pm 0.01^{b}$ & $35.67 \pm 0.01^{b}$ & $20.77 \pm 0.01^{b}$ & $2.60 \pm 0.02^{\mathrm{b}}$ & $21.43 \pm 0.04^{\mathrm{d}}$ \\
\hline Coat & $96.05 \pm 0.07^{\mathrm{a}}$ & $2.15 \pm 0.07^{\mathrm{d}}$ & $12.77 \pm 0.01^{\mathrm{c}}$ & $29.38 \pm 0.02^{\mathrm{a}}$ & $3.00 \pm 0.01^{\mathrm{b}}$ & $50.74 \pm 0.01^{b}$ \\
\hline Flesh & $94.00 \pm 0.01^{\mathrm{b}}$ & $10.20 \pm 0.01^{\mathrm{a}}$ & $10.55 \pm 0.07^{d}$ & $18.18 \pm 0.01^{\mathrm{c}}$ & $2.25 \pm 0.07^{c}$ & $52.80 \pm 0.01^{\mathrm{a}}$ \\
\hline K. cake & $88.44 \pm 0.06^{\mathrm{d}}$ & $4.51 \pm 0.01^{\mathrm{c}}$ & $47.11 \pm 0.01^{\mathrm{a}}$ & $8.54 \pm 0.04^{\mathrm{d}}$ & $5.04 \pm 0.01^{\mathrm{a}}$ & $23.24 \pm 0.02^{\mathrm{c}}$ \\
\hline SEM & 1.19 & 1.15 & 5.82 & 1.89 & 1.62 & 10.20 \\
\hline Sig & $*$ & $*$ & $*$ & $*$ & $*$ & $*$ \\
\hline
\end{tabular}

Means within the same column with different superscripts are significantly different $(\mathrm{P}<0.05)$.

DM : Dry matter.

EE : Ether extract.

$\mathrm{CP}$ : Crude protein.

$\mathrm{CF}$ : Crude fibre.

NFE : Nitrogen free extract.

Sig : Significance level.

SEM : $\quad$ Standard error of means.

SD : Standard deviation. 


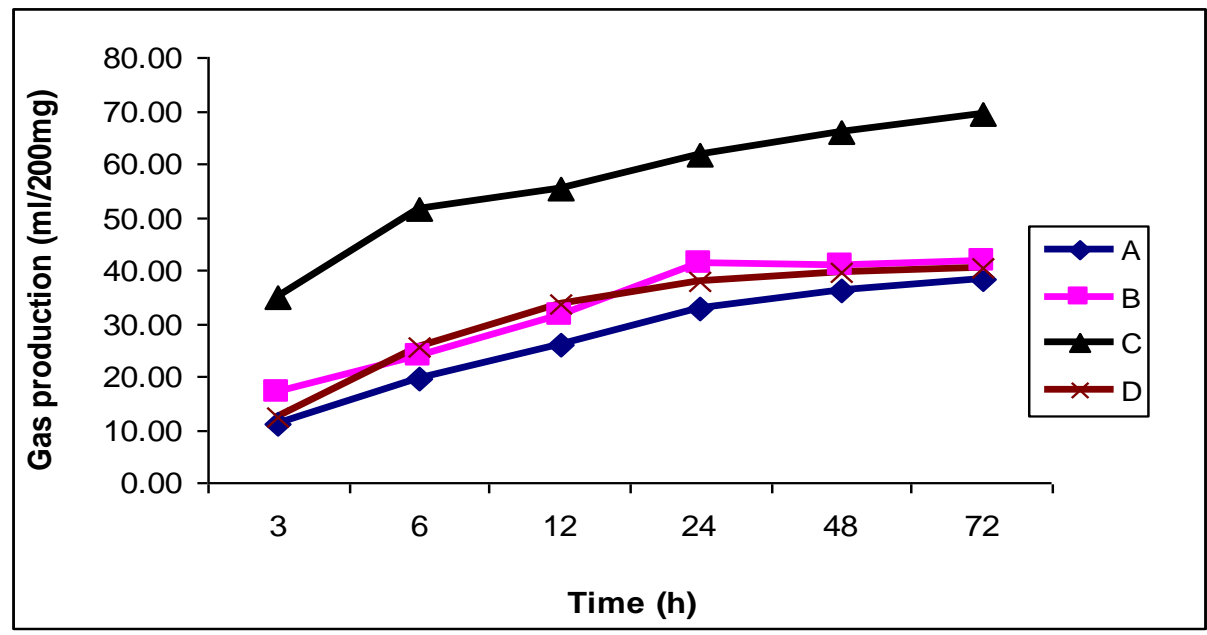

Figure 1: Data of gas production during the incubation period of leaves, coat (hull), flesh (pulp) and kernel seed cake of B. agyptiaca.
A . Leaves of Balanites aegyptiaca.
B . Coat of Balanites aegyptiaca
C . Flesh of Balanites aegyptiaca
D . Kernel cake of Balanites aegyptiaca

Table 2: Estimates of chemical components from the gas production of leaves, coat (hull), flesh (pulp) and kernel seed cake of Balanites aegyptiaca trees.

\begin{tabular}{|l|c|c|c|c|c|c|}
\hline Part & $\mathrm{a}$ & $\mathrm{b}$ & $\mathrm{a}+\mathrm{b}$ & $\mathrm{c}$ & OMD\% & ME (MJ/kgDM) \\
\hline Leaves & $3.50^{\mathrm{b}}$ & $33.73^{\mathrm{ab}}$ & $37.22^{\mathrm{b}}$ & $0.10^{\mathrm{b}}$ & $72.72^{\mathrm{b}}$ & $11.55^{\mathrm{a}}$ \\
Coat & $9.73^{\mathrm{ab}}$ & $21.97^{\mathrm{b}}$ & $31.71^{\mathrm{b}}$ & $0.16^{\mathrm{b}}$ & $59.22^{\mathrm{c}}$ & $8.99^{\mathrm{b}}$ \\
flesh & $22.61^{\mathrm{a}}$ & $44.85^{\mathrm{a}}$ & $67.47^{\mathrm{a}}$ & $0.13^{\mathrm{b}}$ & $67.69^{\mathrm{b}}$ & $11.61^{\mathrm{a}}$ \\
Kernel cake & $-16.09^{\mathrm{c}}$ & $46.70^{\mathrm{a}}$ & $30.61^{\mathrm{b}}$ & $0.25^{\mathrm{a}}$ & $80.82^{\mathrm{a}}$ & $10.40^{\mathrm{a}}$ \\
SEM & 5.66 & 4.61 & 3.41 & 0.03 & 3.59 & 2.01 \\
\hline
\end{tabular}

Means within the same column with differing superscripts are significantly different. $\mathrm{a}=$ the gas production from the immediately soluble fraction $(\mathrm{ml})$,

$\mathrm{b}=$ the gas production from the insoluble fraction $(\mathrm{ml})$.

$\mathrm{c}=$ the gas production rate constant from the insoluble fraction (b).

$\mathrm{a}+\mathrm{b}=$ Potential gas production.

$\mathrm{ME}=$ Metabolisable energy

$\mathrm{OMD}=$ Organic matter digestibility 
The components of the different parts of B. agyptiaca is shown in Table 1. The dry matter (DM) and crude fibre (CF) content varied significantly $(\mathrm{p}<0.05)$ among the different parts. The highest DM and crude fibre (CF) content was observed in the coat while the kernel cake showed the lowest value. The crude protein $(\mathrm{CP})$ content was variable $(\mathrm{p}<0.05)$. The highest CP content $(47.11 \%)$ was found in the cake, followed by the leaves, coat and the lowest $\mathrm{CP}$ was observed in the flesh. Crude fat $(\mathrm{CF})$ and NFE content varied significantly $(\mathrm{p}<0.05)$ among the pulp, kernel and leaves. The highest Crude fat (CF) and NFE content was observed in the flesh and the lowest content in the kernel cake. No significant differences were observed in the ash content among the different parts of B. agyptiaca.

Gas production of the leaves, coat (hull), flesh (pulp) and kernel seed cake of B. agyptiaca at different incubation periods is shown in the Figure 1. It Indicates variation in the B. agyptiaca degradability and digestability potential, As can be seen from Figure 1 the gas production at $24 \mathrm{~h}$ incubation time ranged between 36.00 and 61.00 per.200g of dry matter. The highest gas production was observed in the flesh, while the leaves showed the lowest gas production. The gas production at $24 \mathrm{~h}$ incubation time is consistant with those reported by Mahala and Fadel Elseed, (2007) for A. nilotica and A. Senegalenses tree in the Sudan and Babayemi et al. (2009) for Albizia saman and Albizia rhizonse in Nigeria.

Table 2 shows the parameters estimated from the gas production of leaves, coat (Hull), flesh (Pulp) and kernel seed cake of Balanites aegyptiaca trees.

Gas production from fermentable part (b) and potential gas production $(a+b)$ were significantly $(p<0.001)$ higher in flesh than in the leaves and this may due to high content of NFE in the flesh.

The rate of fermentation fraction (c) was significantly higher in seed than in leaves and the gas production of leaves and seed increased with increasing incubation time as reported by Mahala and Fadel Elseed, (2007); (Khazaal et al., 1995).

Gas produced from fermentable fraction $(b)$ and the potential gas production $(a+b)$ were significantly $(\mathrm{p}<0.001)$ higher in pods than in the leaves. This may be due to their higher content of CP and NDF and low content of TCT, whereas the potential gas production $(a+b)$, is associated with degradability of feed. 
The values of an estimated OMD at 48hrs of $B$ agyptiaca varied between $59.22 \%, 67.69 \%, 72.72 \%$ and 80.82 for kernel seed cake, leaves, coat and flesh respectively. Organic matter digestibility (OMD) varied significantly between the kernel cake and the other parts of $B$. aegyptiaca. Kernel cake had the highest values and this may be attributed to high protein and ash content. OMO of Kernel cake was significantly higher than the values reported by Moboboki et al. (2005) for Acacia tree in South Africa.

ME content of from four different parts of $B$ agyptiaca varied between 8.99 and 17.40 which is consistence with those reported by Moboboki et al. (2005); Ondiek et al. (2010) for Acacia trees in South Africa and Kenya respectively. The calculated Metabolisable energy (ME) content in the flesh was significantly higher than the other parts and this may be attributed to the higher gas production and NFE.

\section{CONCLUSION}

Pulp, kernel cakes, and leaves of B agyptiaca differed significantly with respect to components, in vitro gas production, OMD and ME. Kernel cake and flesh showed the highest values of in vitro gas production, OMD and ME. It is concluded that, flesh and kernel seed cake of $B$. agyptiaca have high nutritive and metabolizable energy content and therefore could be used for ruminants as feedstuffs and more so as protein and carbohydrate supplement to low quality tropical basal diet.

\section{REFERENCES}

Abu-Al-Futuh, IM. (1983): Balanites aegyptiaca: An Unutilized raw material potential ready for agroindustrial exploitation. UNIDO Document no. 12419 project TF/INT/77/021. UNIDO of the United Nations.

Amalraj, V.A. and Shankanarayan, K.A. (1986): Ecological distribution of Balanites roxburghii pl in arid Rajasthan. J. Trop Forestry 2(3): 183-187.

Analytical software, (2000): Statisticx user's manual, Analytical software, Tallah assee, FL. USA.

AOAC, (1990): Official Method of Analysis. Association of Official Analytical Chemists. pp.66-88. 15th edition. Washington, DC. USA. 
Arigbede, O.M.; Anele, J.A.; Olanite, I.O.; Adekunle, O.A.; Jolaosho, A. and Onifade, O.S. (2006): Seasonal in vitro gas production parameters of three multi - purpose trespecies in Abeokuta, Nigeria Department of Pasture and Range Management, College of Animal Science and Livestock Production, University of Agriculture, PMB 2240, Abeokuta, Nigeria.

Babayemi, O.J.; Bamikole, M.A. and Modupe, O.D. (2009): In vitro gas production and its prediction on metabolizable energy, organic matter digestibility and short chain fatty acids of some tropical seeds.Pakistan Journal of Nutrition. 8. (7): 1078-1082.

Badi, K.H.; Elhouri, A. and Bayoumi, A.M. (1989): The forests of the Sudan. Agricultural research Council, Khartoum.

Blummed, M. and Ørskov, E.R. (1993): Comparison of in vitro gas production and Nylon Bag Degradability of rougages in predicting feed intake in cattle. Animal Feed Science and Technology 40: 109-119.

Chapagain, B.P. and Wiesman, Z. (2005): Variation in diosgenin level in kernel among different provenances of B. aegyptiaca Del. (Zygophyllaceae) and its correlation with oil content, Afr. J. Biotechnol. 4 (2005), pp. 1209-1213.

Depeters, E.J.; Getachew, G. and Aseltim, M.S. (2003): Invitro gas production as amethod to compare fermentation characteristics of steam. flaked corn. Anim. Feed Science and Techn. 105: 109-122.

Elfeel, A.A. and Warrag, E.I. (2010): Variation in morphological and chemical characteristics of fruits and seeds among eleven geographical sources of Balanites aegyptiaca (L.) Dell in Sudan. Sudan Silva.12(1)

Elkhiedeir, O.A.; Gumaa, A.Y.; Fangali, O.A.I. and Badir, N.A. (1983): The use of Balanites kernel cake in a diet for fattening sheep., Anim. Feed Sci. and Tech. 9: 301-306.

Elnour, A.A.A.M.; Ahmed, A.H.R. and Abdel Gayoum, A.G.A. (1985): A chemical study of Balanites aegyptiaca L.(Lalobe) fruits grown in Sudan. J. Sci. Food Agric. 36: 125, 1254-1258.

Guinand, Y. and Dechassa, L. (2002): Ethiopia: Famine Food Guide(http://www.africa.upenn.edu/faminefood/categoryl.htm: accessed on 27 June 2004)

Hall, J.B. and Walker, D.H. (1991): Balanites aegyptiaca; A monograph. School of Agricultural and Forest Science Puplication, University of Wales, No. 3. 
Katende, A.; Birne, A. and Tengnas, B. (1995): Useful trees and shrubs for Uganda. Identification, propagation and management for agriculture and pastoral communities. Kampala and Nairobi. Regional Soil Conservation Unit. RSCU/SIDA Technical Handbook Series 10.

Khazaal, K.A.; Dentio, M.T.; Ribeiro, J.M. and Ørskove, E.R. (1995): Prediction of apparent digestibility and voluntary intake of hays fed to sheep: comparison between using fiber components, in vitro digestibility or characteristics of gas production or nylon bag degradation. Animal Sci. 61: 527-538.

Mahala, A.G. and Fadel Elseed, A.A. (2007): Chemicalcomposition and invitro gas production characteristic of fooder tree leaves and seeds, Research journal of Agricultural and Biological Sciences. 3: 983-986.

Maker, H.P.; Goodchild, A.V. and Beaker, K. (1996): Cell- constituents, tennin levels by chemical and biological assays and nutritional value of some legume folige and straw. Journal of Food and Agriculture. 71: 129-136.

Menke, K.H.; Raab, A.; Salewski, H.; Sateingass, D.; Fritz, L. and Schneider, W. (1979): The estimation of digestibility and metabolizable energy content of ruminant's feedstuffs from the gas production when they incubated with rumen liquor in vitro. J. Agric. Sic. (Cambridge). 92: 217-222.

Menke, K.H. and Steingass, H. (1988): Estimation of energetic feed value obtained from chemical analysis and gas production using rumen fluid. Anim. Res. Development, 28: 7-55.

Mohamed, A.M.; Wolf, W.; and Speiss, W. (2002): Physical, morphological and chemical characteristics, oil recovery and fatty acid composition of Balanites aegyptiaca Kernels. Plant Foods for Human Nutrition57 (2): 179-189.

Mokoboki, H.K.; Ndlova, L.R.; Ngambi, J.W.; Malatje, M.M. and Nikolova, R.V. (2005): Nutritive value of Acacia tree foliages growing in the Limpopo Province of South Africa.South Africa Journal of Anim. Sci. 35 (4) 221-228.

Natinal Research Council, (2008): Lost Crops of Africa: Volume III, Fruits, Development, Security and Cooperation. The National Academies Press, Washington, D.C.

Ondiek, J.O.; Abdulrazak, S.A. and Njoka, E.N. (2010): Chemical and mineral composition, in-vitro gas production, in - sacco 
gegradation of selected indigenous Kenyan browse. Livestock research for rural development 22: (2).

Opatpatanakit, Y.; Kellawya, R.; CleanI, J.; Annison, G. and Kirby, A. (1994): Microbial ermentation of cereal grains in vitro.Astralian Journal of Agriculture Research 45: 1247-1263.

Ørskove, E.R. and McDonald, P. (1979): The estimation of protein degradability in the rumen from incubation measurements weighed according to rate of passage. J. Agric. Sci. 92: 499-503.

Schmidt, L.H. and Dorthe, J. (2000): Balanites aegyptiaca (L) Dell. Danida Forest Seed Centre seed leaflet No. 21. DFSC, Denmark.

Strecter, M.N.; Hill, G.M. and Owens, F.N. (1993): Chemical and physical properties and invitro dry matter and starch digestion of eighth sorghum grain hybrids and maize. Ani. feed Sci and Tech, 44: 45-58.

Vogt, K. (1995): Afield guide to the identification propagation and uses of common trees and shrubs of dry land Sudan. SOS Sahel International (UK).

Von Maydell, H.J. (1986): Trees and shrubs of the Sahel: their characteristics and uses. Eschborn, GTZ, Germany. 
Assiut Vet. Med. J. Vol. 57 No. 130 July 2011 